\title{
Performance of Smallholder Irrigation Schemes in the Vhembe District of South Africa
}

\author{
Wim Van Averbeke \\ Tshwane University of Technology \\ South Africa
}

\section{Introduction}

South Africa needs to raise employment and reduce poverty, particularly among rural African people. The New Growth Path released by the government in November 2010 was a response to the persistent unemployment problem. It aims to create five million new jobs by 2020. The New Growth Path intends to create 300000 of these new jobs through the establishment of smallholder farmer schemes (Department of Economic Development, 2010). This suggests that policymakers believe that smallholder scheme development can create a substantial number of new employment opportunities in South Africa. However, the performance of the smallholder schemes that have been set up as part of the postdemocratisation land reform programme has been dismal (Umhlaba, 2010). Assessments of smallholder irrigation schemes indicated that many of them also performed poorly (Bembridge, 2000; Machete et al., 2004; Tlou et al., 2006; Mnkeni et al., 2010). Yet, in waterstressed South Africa, expanding smallholder irrigation is one of the obvious options to trigger rural economic development. Elsewhere in the world, particularly in Asia, investment in irrigation was a key ingredient of the green revolution, which lifted large numbers of rural Asians out of poverty and created conditions that were conducive for the industrial and economic development that has occurred (Turral et al., 2010). A similar development trajectory has been recommended for South Africa and other parts of SubSaharan Africa (Lipton, 1996). So far, the developmental impact of smallholder irrigation in Sub-Saharan Africa has been limited (Inocencio et al., 2007).

In this chapter, associations between selected performance indicators and attributes of smallholder irrigation schemes in the Vhembe District of Limpopo Province, South Africa, are examined. For the purpose of this chapter, smallholder irrigation scheme was defined as an as an agricultural project that was constructed specifically for occupation by African farmers and that involved multiple holdings, which depended on a shared distribution system for access to irrigation water and in some cases also on a shared water storage or diversion facility. In 2011, there were 302 smallholder irrigation schemes in South Africa with a combined command area of 47667 ha.

The objective of this chapter was to identify factors that had a significant effect on smallholder irrigation scheme performance. Knowledge of such factors could assist effective location and design of new schemes. Before focussing on the study itself, it was deemed important to provide a background to African smallholder agriculture in South Africa in 
general and smallholder irrigation scheme development in particular. This is done in the first part of this chapter. The study area and the materials and methods used to assess the population of smallholder irrigation schemes in the study area are presented in the second part. The results of the study are presented next. First, the characteristics of population of smallholder schemes in the study area are described. Next, the associations between a selection of smallholder scheme characteristics and four performance indicators are examined statistically. In the last part the results of the study are discussed and interpreted.

\section{African smallholder agriculture and irrigation in South Africa: A brief history}

\subsection{African smallholder agriculture}

In South Africa, traditional agriculture was disturbed in major ways by military and political subjugation of the different African tribes during the nineteenth century, followed by land dispossession, segregation and separation. These processes restricted the area where Africans held farm land to relatively small parts of the country, which combined covered about 13\% of the total land area in 1994 (Vink \& Kirsten, 2003). Over time, the territories in which Africans held land have been referred to as Native Areas, Bantu Areas, Bantustans and homelands but in this text the term homelands will be used to reflect the situation just prior to democratisation of South Africa in 1994. From when they were created in 1913, the homelands have been characterised by high rural population densities, small individual allotments of arable land and shared access to rangeland. The rangeland that was available to communities was inadequate to support sufficient livestock to meet even the most basic requirements of African homesteads in terms of draught power, milk, wool, meat and social needs (Lewis, 1984; Bundy, 1988; Mills \& Wilson, 1952). African homesteads diversified their livelihoods in response to the lack of room to reproduce their land-based lifestyles. Until about 1970, migrant remittances, mostly from male members who worked in mines and cities, supported the reproduction of African rural homesteads (Beinart, 2001). From 1970 to 1990, income earned from employment inside the homelands became important (Leibbrandt \& Sperber, 1997; Beinart, 2001). Homelands received substantial budget allocations from separatist South Africa to attend to local economic and social development. Employment was created in education, bureaucracy and business (Beinart, 2001). From 1990 onwards, rural homesteads increasingly depended of claiming against the state, in the form of old-age pensions and child support grants (Shah et al., 2002; Van Averbeke \& Hebinck, 2007; Aliber \& Hart, 2009; De Wet, 2011).

Despite the lack of room to farm, agricultural activities remained central in the livelihood strategy of a majority of rural homesteads until about 1950, even though the proportional and nominal contribution of agriculture to homestead income had been in decline for much longer (Houghton, 1955; Tomlinson Commission, 1955; Bundy, 1988). After 1950, rural African homesteads progressively withdrew from cultivating their arable allotments. For example, in Ciskei the cultivation of arable land dropped from an average of $82 \%$ in 1950 (Houghton, 1955) to 10\% in 2006 (De Wet, 2010). Whilst the decline in cultivation has not necessarily been as dramatic in all homeland areas as it has been in Ciskei, the trend has been universal. As a result, for most African rural homesteads farming has become a livelihood activity that is of secondary importance. In 2006, of the 1.3 million African households with access to an arable allotment, only $8 \%$ listed agriculture as their main 
source of food. For less than one in ten households (9\%) agriculture was a source of monetary income, with $3 \%$ referring to farming as their main source of income and $6 \%$ as an additional source of income. For the large majority, farming was merely an additional source of food (Aliber \& Hart, 2009; Vink \& Van Rooyen, 2009).

The deterioration of African farming received government attention from 1917 onwards (Beinart, 2003). Initial interventions were focused on the conservation of the natural resource base in the homelands. Land use planning, conservation of arable land using erosion control measures, rotational grazing using fenced grazing camps and livestock reduction schemes were some of the important measures taken by the state to check natural resource degradation (Beinart, 2003). More land was made available to reduce growing landlessness but these interventions had no positive impact on agricultural production. Overcrowding as the principal cause for the inability of African smallholders to produce enough to feed themselves, let alone make a living of the land, was pointed out by the Commission for the Socio-Economic Development of the Bantu Areas within the Union of South Africa (1955). This Commission was referred to as the Tomlinson Commission (1955) after Professor F.R. Tomlinson, who was its Chairperson. The Tomlinson Commission (1955) proposed the partial depopulation of the homelands to avail enough room for those who were to remain on the land to make a living from full-time farming. Expansion of irrigated farming, by upgrading existing irrigation schemes and establishing new schemes in the homelands, was one of the strategies proposed by the Tomlinson Commission (1955) to create new opportunities for African homesteads to make a full-time living from smallholder agriculture. The Tomlinson Commission (1955) had identified that smallholders on some of the existing irrigation schemes were making a decent living on irrigated plots of about 1.28 ha combined with access to enough grazing land to keep a herd of six cattle, which was the minimum number required for animal draught power. The master plan of the Tomlinson Commission (1955) to reduce the population in the homelands and establish economically viable farm units for African homesteads was never implemented. The proposal to expand smallholder irrigation did receive attention. It played an important role in irrigation scheme development in the Vhembe District, which will be discussed later.

\subsection{African smallholder irrigation schemes}

The use of irrigation by African farmers in South Africa appears to have two centres of origin. One of these centres was the Ciskei region of the Eastern Cape, where technology transfer from colonialists to the local people, resulted in the adoption of irrigated agriculture by African peasants (Bundy, 1988). These early smallholder irrigation developments were mostly private or mission station initiatives and involved river diversion. Most of these early African irrigation initiatives in the Eastern Cape did not last long (Houghton, 1955, Bundy, 1988). The other centre of origin was located in what is now the Vhembe District. Evidence of African irrigation in this area was provided by Stayt (1968), who conducted anthropological research among the Venda during the late nineteen-twenties and published the first account of his work in 1931. Box 1 cites Stayt's reference to African irrigation in Vhembe. This reference to early African irrigation in Vhembe contained in Box 1 is significant for two reasons, namely the apparent use of irrigated agriculture by local African people before exposure to European colonialists and their continued use, or at least readoption, of irrigated agriculture using stream diversion during the nineteen-thirties,. This 
suggests local interest, knowledge and affinity for the use of irrigation as a way of intensifying crop production.

In the northwest of Vendaland there are traces of some very ancient occupation. Colonel Piet Moller, who was an early settler in the Zoutpansberg, has found what he considers indisputable evidence of ancient irrigation works. Most of the old furrows are near Chepisse and it appears that the water was diverted from a small stream there in a series of furrows to a distance of about four and a half miles south. Traces of furrows are also discernable at Sulphur Springs, and at several places by the Nzhelele river, where some of them have been reopened and are utilised by the BaVenda to-day. Colonel Moller says that when he first came across these some forty years ago (around 1880), there was no doubt about their antiquity; to-day they are very difficult to trace, as roads, modern agriculture, and furrows have altered the face of the country considerably and have particularly hidden the ancient workings.

Box 1. Reference to African irrigation in Vhembe (Stayt, 1968)

The Tomlinson Commission (1955) also identified the northern parts of South Africa as the area where smallholder irrigation schemes were functioning best, as is evident from its statement reproduced in Box 2 .

Among the various systems and types of settlement in the Bantu Areas, irrigation farming is undoubtedly the only form of undertaking in which, under European leadership and control, the Bantu have shown themselves capable of making a full-time living from farming, and of making advantageous use of the soil for food production.

The interest shown by Bantu in irrigation farming varies from one locality to another. In some parts of the Transvaal (here reference is made to areas that are now part of Limpopo Province), the Bantu are so enthusiastic that they offer their labour free to construct canals to lead water from streams for the irrigation of their land, while in the Transkei and Ciskei (now part of the Eastern Cape), on the contrary, interest has waned to such a degree, that existing schemes have fallen into disuse.

Box 2. Reference to the performance of African smallholders on irrigation schemes during the period 1950-52 by the Tomlinson Commission (1955)

In 1952, when the Tomlinson Commission completed its data collection, it identified 122 smallholder irrigation schemes covering a total of 11406 ha. This irrigated area was held by 7538 plot holders, each holding a plot with an average size of 1.513 ha. All of these were river diversion schemes but it is not clear whether the water conveyance and distribution systems were lined or not. The Tomlinson Commission (1955) did distinguish between what appeared to be indigenous and state controlled irrigation projects, identifying state controlled schemes as performing considerably better than those controlled by African farmers themselves (Box 3).

The 'European control' mentioned in Box 3 referred to a set of institutional arrangements imposed by the state, which regulated allocation of water to farmers and land use, including 
choice of crops, and the provision of technical advice and marketing assistance for the crops that were prescribed to farmers. In line with this observation, the Tomlinson Commission (1955) recommended the construction of new smallholder irrigation schemes and the upgrading of existing schemes as a smallholder development strategy. The Tomlinson Commission (1955) identified a total area of 54051 ha that had the potential for irrigation development in Bantu Areas and estimated that exploitation of this potential could enable the settlement of 36000 farmer families, representing approximately 216000 people. The Tomlinson Commission (1955) recommended that irrigation scheme development should occur in the form of simple canal schemes using river diversion by means of a weir and that uniform regulations should be applied to the running of these schemes. One of these regulations was that ownership and control over tribal land identified for irrigation scheme development needed to be transferred to the state before construction of the scheme. Another was that homesteads would be allocated plots that were 1.28 ha to 1.71 ha in size, as these were deemed adequate to provide for a livelihood based on full-time farming. A third was the enforcement of specified production systems on smallholder irrigation schemes. These production systems were to be designed, enforced and supported by stateappointed superintendents. Farmers who settled on these schemes held their plots under Trust tenure. This form of tenure provided the state with the necessary powers to prescribe land use and to expel and replace farmers whose practices did not comply with these prescriptions. In selected cases the state effectively used these powers to enforce the overall objectives of the schemes by evicting poorly performing families (Van Averbeke, 2008). This authoritarian and paternalistic approach by the state was not limited to irrigation schemes settled by Africans. The same approach had been used on state schemes established for settlement by white farmers during the Great Depression and WWII period (Backeberg and Groenewald, 1995).

The Commission collected details of the production achieved on the controlled Olifants River irrigation scheme and the uncontrolled Njelele River scheme (Vhembe District). The average size holding were 1.53 morgen $(1.3 \mathrm{ha})$ and 1.71 morgen $(1.5 \mathrm{ha})$, respectively, and other physical factors were approximately equal. It was found that the average income per settler on the Olifants scheme was $£ 110.69$ as compared with $£ 28.79$ on the Njelele scheme. The average yield of grain of all sorts was 47.07 bags $(4270 \mathrm{~kg}$ ) (fil in) per settler on the Olifants, as against 9.2 bags $(835 \mathrm{~kg})$ on the Njelele scheme. This is a clear indication that irrigation schemes for Bantu are successful when under efficient control and guidance and that the average Bantu family on 1.5 morgen (1.28 ha) under such schemes, can make a gross income of $£ 110.7$ per annum, which renders it unnecessary for members of the family to seek employment elsewhere to supplement the family income.

Box 3. Comparison of the performance of African smallholders on indigenous irrigation schemes with those on irrigation schemes under state control (Tomlinson Commission, 1955)

Construction of smallholder canal schemes in South Africa was continued until the nineteen-seventies. The 2011 update of the smallholder irrigation scheme data base created by Denison and Manona (2007) indicated that there were 74 smallholder canal schemes left in South Africa. Sixty-seven of these were operational, six were not operational and of one scheme the operational status was not known. The combined command area of existing gravity-fed canal schemes was 11966.2 ha, which represented $25.1 \%$ of the total smallholder 
irrigation scheme command area in South Africa. Surface irrigation was also practised on 20 schemes that used pumping, sometimes in combination with gravity. Among these 20 schemes, 14 of were operational and six were not. Combined they had a command area of 4 $113.7 \mathrm{ha}, 8.6 \%$ of the total.

From the nineteen-seventies onwards, the design of smallholder irrigation schemes in South Africa was influenced by the modernisation paradigm. This paradigm was based on the belief that modern, capital-intensive infrastructure, to be paid for by the intensive production of high-value crops, could lift smallholders out of poverty (Faurès et al., 2007). Pumping and overhead irrigation became the norm in smallholder irrigation scheme development in South Africa. In 2011, there were 175 smallholder irrigation schemes that used overhead irrigation. Combined they had a command area of 27757.6 ha, $58.2 \%$ of the total. Among these 175 schemes, 111 were operational, 59 were not and of five the operational status was not known. Pumped overhead schemes covered a total command area of 16497.1 ha, gravity-fed overhead schemes 4451 ha and schemes where gravity and pumping occurred in combination had a total command area of 6903.5 ha.

Distinctive of the modernisation paradigm in smallholder irrigation scheme development was the establishment of large projects. In many of the large smallholder schemes that were constructed in South Africa, the design was characterised by functional diversification and centralisation of scheme management. Typically, these large schemes were designed to perform three functions, namely a commercial function, a commercial smallholder development function and a subsistence function. The commercial function was performed by allocating a substantial part of the scheme area to a central unit that was farmed as an estate. Farming on this estate used management and labour (Van Averbeke et al., 1998). The commercial smallholder development function was implemented by allocating a limited number of 'mini-farms' to selected African homesteads, who were judged to have the aptitude to make a success of small-scale commercial agriculture. These mini-farms ranged between 5 ha and 12 ha in size. (Van Averbeke et al., 1998), The subsistence function was put into practice by providing large numbers of African homesteads with access to food plots, ranging from 0.1 ha to 0.3 ha in size (Van Averbeke et al., 1998). In some instances complex arrangements had to be made to implement this multi-functional design, because land holders had to be compensated for handing over their dryland allotments to create room for the central unit estate. A good example was the 2830 ha Ncora Irrigation Scheme, established in 1976 in the Transkei region of the Eastern Cape. In return for availing their allotments to the scheme, the 1200 existing land holders at Ncora were offered the right to 0.9 ha of irrigation land. They were given the choice of farming the entire allocation themselves or handing over two-thirds of their allotment to the central unit and remain with a 0.3 ha plot for own use. The latter option provided land holders with production inputs free of charge and an annual dividend derived from the profits made by the central unit. Management of these large schemes was centralised and in the hands of specialised parastatals established by homeland governments (Van Rooyen \& Nene, 1996; Van Averbeke et al., 1998; Lahiff, 2000). The financial viability of this type of smallholder schemes was dependent on the performance of the central unit. Records show that the financial performance of these central units never met the predictions (Van Averbeke et al., 1998). State subsidies were persistently required to keep these schemes afloat. Taking an extreme example, in 1995, the central unit of Ncora Irrigation Scheme required a budget of R21.3 million. It had 650 employees at a cost R16.6 million and operational costs amounting 
to R4.8 million. The income of the central unit in 1995 was R2.8 million, way short of even meeting its operational costs.

Following the democratisation of South Africa in 1994, the provincial governments decided to dismantle the agricultural homeland parastatals and transfer the management of smallholder irrigation schemes to the farmer communities who benefitted from them. Elsewhere in the world, a similar process, referred to as 'Irrigation Management Transfer' (IMT) had been occurring. Reducing public expenditure on irrigation, improving productivity of irrigation and stabilising of deteriorating irrigation systems were the three main reasons why IMT was implemented by governments (Vermillion, 1997). In South Africa, the dismantling of homeland parastatals and IMT proceeded very swiftly. It started in 1996 in the Eastern Cape and ended in 1998 in Limpopo Province. IMT affected all projects where parastatals were offering services to smallholders. Its effects were most strongly felt on the large, modern smallholder irrigation schemes, because these projects were the most complex to manage. Having been centrally managed from inception, levels of dependency on external management among farmers on these schemes were exceptionally high (Van Averbeke et al., 1998). Farming collapsed as soon as IMT had been implemented on these schemes (Bembridge, 2000; Laker, 2004). Small irrigation schemes, particularly the canal schemes, were more resilient and continued to operate, albeit at reduced levels (Kamara et al., 2001; Machete et al., 2004).

Besides IMT, the nineteen-nineties also saw the establishment of several new smallholder irrigation schemes. Conceptually, these new schemes were aligned with the Reconstruction and Development Programme (RDP). This Programme was the national development framework that applied at that time. It was aimed at eradicating poverty and improving the quality of life among poor African people in rural areas and informal urban settlements. Irrigation development focused on improving food security at community or group level and favoured the establishment of small schemes. In 2006, Denison and Manona (2007) identified 62 smallholder irrigation schemes that were established during this era, but combined they only covered 2383 ha, clearly indicating their limited size (38.4 ha on average). Typically, these projects used mechanical pump and sprinkler technology to extract and apply irrigation water.

When GEAR (Growth, Employment and Redistribution) superseded the RDP as the overall development policy of South Africa, the strategy to eradicate poverty shifted from funding community-based projects to pursuing economic growth through private sector development. Existing irrigation schemes were identified as important resources for the economic development of the rural areas, but they required revitalisation first. The Revitalisation of Smallholder Irrigation Schemes (RESIS) of the Limpopo Province stood out for its comprehensiveness. The RESIS programme evolved from the WaterCare programme, which was launched in 1998 and ran for five years (Denison and Manona, 2007). The WaterCare programme was aimed at revitalizing selected smallholder irrigation schemes in the Province, not only infrastructurally, but also in terms of leadership, management and productivity. Using a participatory approach, WaterCare involved smallholder communities in planning and decision making and provided training to enable these communities to take full management responsibility over their schemes (Denison \& Manona, 2007). In February 2000, Mozambique and the Limpopo Province were ravaged by cyclone Conny (Christie \& Hanlon, 2001). Heavy rains caused widespread floods and damage to roads, bridges and 
also to the weirs that provided water to many of the smallholder canal schemes (Khandlhela \& May, 2006). Declared a disaster area, the Limpopo Province was allocated special funding to repair the damage to its infrastructure, providing impetus to the WaterCare programme. In 2002, the Limpopo Province broadened the scope of its irrigation scheme rehabilitation intervention by launching a comprehensive revitalisation programme, called RESIS (REvitalisation of Smallholder Irrigation Schemes). RESIS adopted the participatory approach of the WaterCare programme, but planned to revitalise all smallholder schemes in the Province (Denison \& Manona, 2007). As was the case in the WaterCare programme, RESIS combined the reconstruction of smallholder irrigation infrastructure with the provision of support to enable effective IMT. In support of IMT, the programme dedicated one-third of the revitalisation budget to capacity building among farmers. Guidelines for the sustainable revitalisation of smallholder irrigation schemes, which covered the building of capacity among irrigator communities were developed by De Lange et al.(2000). RESIS also sought to enhance commercialisation of the smallholder farming systems on the schemes, in order to improve the livelihood of plot holder homesteads (Van Averbeke, 2008).

During the WaterCare programme and the first phase of RESIS (1998-2005), the emphasis was primarily on the rehabilitation of the existing scheme infrastructure and on sustainable IMT, and less on commercialisation. Canal schemes that were revitalised during this phase remained canal schemes. However, in 2005, commercialisation became the principal development objective of RESIS. The shift in emphasis was probably influenced by the Black Economic Empowerment (BEE) strategy that was introduced in South Africa, first in the mining sector and later on also in other sectors of the economy, including agriculture (Van Averbeke, 2008). Nationally, the BEE strategy was aimed at increasing the share of black people in the economy and it emphasized entrepreneurship. In 2005, the Limpopo Department of Agriculture launched the second phase of RESIS, named RESIS-RECHARGE. The Department equated canal irrigation with subsistence farming and inefficient water use. Consequently, it discouraged and later on rejected revitalisation of canal infrastructure. Instead it funded the transformation of canal schemes into schemes that used modern irrigation technology, such as micro-irrigation, centre pivot and floppy sprinkler systems. Implementation of these new irrigation systems obliterated existing plot boundaries. To get production on these revitalised modern schemes on a commercial footing, the Department engaged the services of a strategic partner in the form of a commercial farmer, who was tasked with running the entire operation. Plot holders were compensated for availing their land holdings by means of dividends, which amounted to half of the net operating income. They no longer had an active part in farming. In the Vhembe District, two smallholder irrigation schemes were revitalised in this way, namely Makuleke and Block 1A of the Tshiombo scheme. The others remained unaffected. With reference to the use of microirrigation on smallholder irrigation schemes in South Africa, in 2011 there were 20 such schemes, 11 operational and nine non-operational. Combined they had a command area of 3 830 ha, $8.0 \%$ of the total.

\section{Performance of smallholder irrigation schemes in South Africa}

Globally, assessment of the performance of irrigated agriculture has received considerable attention, not in the least because of growing competition for water from other sectors (Faurès et al., 2007). Molden et al. (1998) developed a set of nine indicators to enable 
comparison of irrigation performance across irrigation systems. These covered irrigated agricultural output, water supply and financial returns. However, for smallholder irrigation schemes in South Africa the data required to calculate the nine indicators are rarely available. Most investigations into the performance of South African smallholder irrigation schemes used operational status, condition of the irrigation system, observations of cropping intensity and farm income in selected instances for assessment purposes. Generally, the conclusion of these studies has been that the contribution of smallholder irrigation schemes to social and economic development of irrigation communities has been far below expectations. (Bembridge \& Sebotja, 1992; Bembridge, 1997; Bembridge, 2000; Machete et al., 2004; Tlou et al., 2006; Fanadzo et al., 2010). However, against a background of poor performance of smallholder irrigation schemes, few if any of the studies attempted to identify factors that appeared to contribute to differences in performance among these schemes. Such information could assist effective location and design of new schemes and also suggest priorities when planning the revitalisation of existing schemes.

\section{Materials and methods}

The Vhembe District is located in the Limpopo Province of South Africa (Fig.1), and is the most northern district of the Limpopo Province (Fig.2).

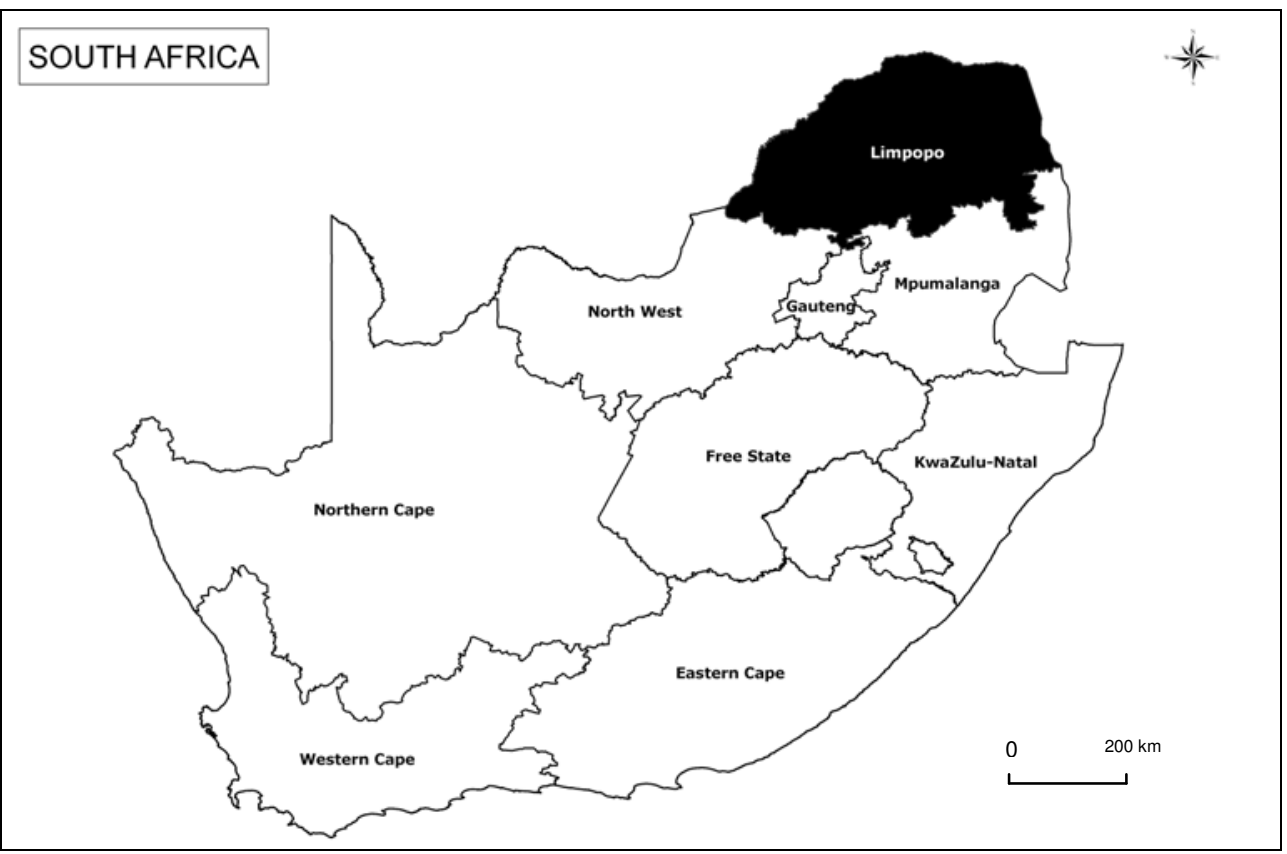

Fig. 1. The Limpopo Province in the north of South Africa

Vhembe borders Zimbabwe in the north and Mozambique in the east. It incorporates the territories of two former homelands, namely Venda and Gazankulu. The Venda homeland 
was created for the Venda-speaking people. Gazankulu was the territory allocated to the Tsonga-speaking people, also known as the Shangaan. Culturally, the BaVenda are closely associated with the Shona people of Zimbabwe, whilst the cultural roots of the Shangaan are in Mozambique.

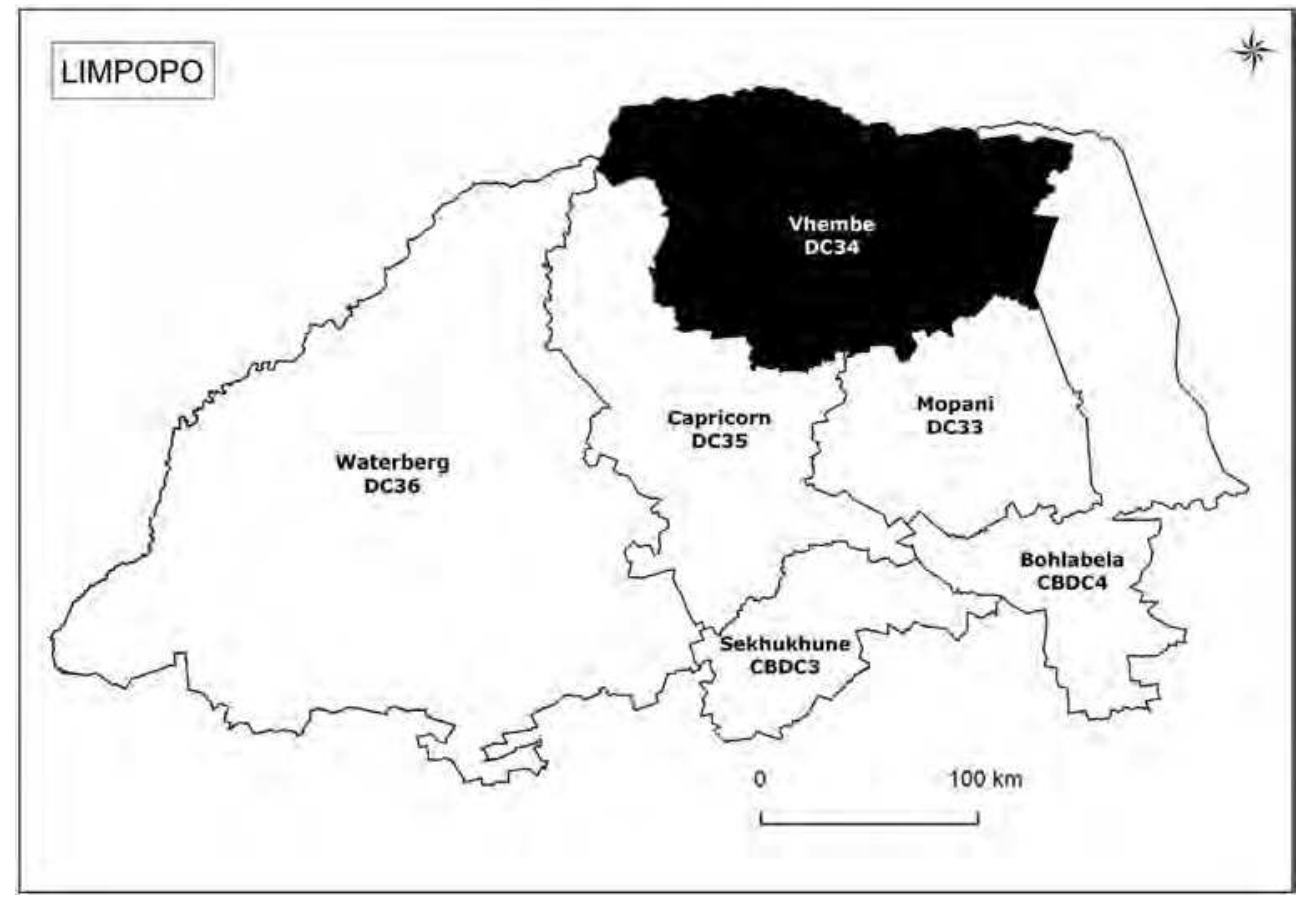

Fig. 2. Location of the Vhembe District in the Limpopo Province

Smallholder irrigation schemes in the Vhembe District were studied by means of a census. The census covered all smallholder irrigation schemes contained in the Vhembe register of the Limpopo Department of Agriculture, which was used as the sampling frame. A structured interview schedule was compiled for use as the survey instrument. The survey was conducted over a period of 10 months and involved four visits to the study area, each lasting between five and ten days. Work started in November 2008 and the last schemes on the list were visited during August 2009. Subsequently, the field data were scrutinised to identify data that were missing or needed verification. All the data queries that were identified were resolved during a follow-up visit to the study area in November 2009. Care was taken to achieve the greatest possible degree of reliability. Where possible, a small panel consisting of farmers, preferably members of the scheme management, and the extension officer were interviewed. At a few schemes only the extension officer or only farmers participated in the interview. Following the completion of the interview, a transect walk of the scheme was done and pictures were taken of selected features. A total of 42 schemes were identified but data collection at the Tshiombo Irrigation Scheme was done for each of the seven sub-units because of important differences amongst them. All other schemes were 
not subdivided, even when they consisted of multiple hydraulic units, referred to as irrigation blocks.

The first level of analysis was aimed at describing the population of smallholder irrigation schemes in the study area. For this analysis, the population was described one variable at a time, using descriptive statistics to generate summaries. The results provided a useful indication of the issues that affected smallholder irrigation in the study area and the diversity that surrounded these issues. The second level of analysis involved the testing of associations between four variables that were selected as performance indicators and a selection of independent variables that described the schemes.

The four performance indicators were operational status, number of years the scheme had been in operation, cropping intensity and degree of commercialisation. Operational status was selected because it is the primary indicator of performance. Once a scheme has stopped to operate, land use reverts to dryland agriculture. The number of years a scheme had been in operation was selected as an indicator of the durability of the system, which, in turn affects the rate of return on investment. Cropping intensity is a widely used indicator of the intensity with which water and land is being used in irrigated agriculture (Molden et al. 2007). Degree of commercialisation was selected because commercialisation has been shown to increase production and accelerate linkages in smallholder agriculture (Makhura et al., 1998).

The scheme characteristics that were considered in the analysis are shown in Table 1.

\begin{tabular}{|c|c|c|c|c|c|}
\hline \multirow[b]{2}{*}{$\begin{array}{l}\text { Scheme } \\
\text { characteristic }\end{array}$} & \multirow[b]{2}{*}{ Ranking criteria } & \multicolumn{4}{|c|}{ Performance indicator } \\
\hline & & $\begin{array}{c}\text { Operationa } \\
\text { status } \\
(\mathrm{n}=48)\end{array}$ & $\begin{array}{c}\text { No of years } \\
\text { in operatior } \\
(\mathrm{n}=48)\end{array}$ & $\begin{array}{c}\text { Cropping } \\
\text { intensity } \\
(\mathrm{n}=35)\end{array}$ & $\begin{array}{c}\text { Degree of } \\
\text { commercialisation } \\
(\mathrm{n}=35)\end{array}$ \\
\hline Hydraulic head & $1=$ gravity $; 2=$ pumped & Yes & \begin{tabular}{|l|} 
Yes \\
\end{tabular} & Yes & Yes \\
\hline Irrigation method & $\begin{array}{l}1=\text { surface; } 2 \text { = overhead; } \\
3=\text { micro }\end{array}$ & Yes & Yes & Yes & Yes \\
\hline Scheme area & Command area (ha) & Yes & Yes & No & No \\
\hline No of plot holders & Population count & No & Yes & No & No \\
\hline Plot size & Plot size (ha) & No & Yes & Yes & Yes \\
\hline $\begin{array}{l}\text { Organisation of } \\
\text { production }\end{array}$ & $1=$ individual $; 2=$ group & No & Yes & No & No \\
\hline $\begin{array}{l}\text { Water restrictions } \\
\text { at scheme level }\end{array}$ & $\begin{array}{l}1=\text { no restrictions; } 2= \\
\text { seasonal restrictions; } 3= \\
\text { perpetual restrictions }\end{array}$ & No & No & Yes & No \\
\hline $\begin{array}{l}\text { Cash based land } \\
\text { exchanges }\end{array}$ & $\begin{array}{l}0=\text { not practised; } 1= \\
\text { practised }\end{array}$ & No & No & Yes & Yes \\
\hline Water theft & $\begin{array}{l}0=\text { not practised; } 1= \\
\text { practised }\end{array}$ & No & No & Yes & No \\
\hline $\begin{array}{l}\text { Effectiveness of } \\
\text { scheme fence }\end{array}$ & $\begin{array}{l}1=\text { effective; } 2=\text { partially } \\
\text { effective; } 3=\text { not effective }\end{array}$ & No & No & Yes & No \\
\hline $\begin{array}{l}\text { Distance to urban } \\
\text { centre }\end{array}$ & Distance by road (km) & No & No & Yes & Yes \\
\hline
\end{tabular}

Table 1. Selected characteristics of smallholder irrigation schemes in Vhembe, their ranking and the association of the performance indicators they were tested for 
Inclusion of the scheme characteristics shown in Table 1 was justified as follows: hydraulic head for its direct effect on operational costs; irrigation method as an indicator of modernisation; scheme area and number of plot holders as indicators of management complexity; plot size for its association with degree of commercialisation identified in other studies (Van Averbeke et al., 1998; Bembridge, 2000; Machete et al., 2004); organisation of production, because group-based land reform projects have been shown to be prone to failure (Umhlaba, 2009); water restrictions because water is a production factor (Perry \& Narayanamurthy, 1998); cash based land exchanges as an indicator of social and institutional responsiveness to demand for land (Shah et al., 2002); water theft as an indicator of social order (Letsoalo \& van Averbeke, 2006); effectiveness of the scheme fence as a recurrent constraint in smallholder agriculture; and distance to urban centre as a measure of access to sizeable produce markets. Associations between scheme performance and scheme characteristics were assessed using Spearman's rank correlation. Scheme characteristics, their ranking and the association of the performance indicators they were tested for, are shown in Table 1. All 48 schemes were included in the analysis of operational status and number of years the scheme had been in operation. Schemes that were not operational (11), as well as two schemes that were no longer managed by plot holders following their revitalisation were excluded from the analysis of cropping intensity and degree of commercialisation.

\section{Results}

\subsection{Summary description of smallholder irrigation schemes in Vhembe}

Selected characteristics of the smallholder irrigation schemes in Vhembe District are presented in Table 2. Keeping in mind that the seven hydraulic units of Tshiombo were treated as separate schemes, 37 (77\%) of the 48 smallholder schemes were operational and 11 were not. The smallest among the 48 schemes, Klein Tshipise, had a command area of only 8.5 ha, whilst the largest, Tshiombo, had a command area of 847 ha when its seven sub-units were combined. Together, the 48 schemes covered a total command area of 3760.1 ha, of which 3012.4 ha $(80 \%)$ was located on schemes that were operational. The actual irrigated area on the schemes that were operational was 2693.1 ha. Two reasons were identified for the difference of 319.3 ha between command area and actual irrigated area on operational schemes. The first was infrastructural malfunctioning, which resulted in parts of the command area being withdrawn from irrigation. Schemes affected and areas involved were Khumbe (59 ha), Dopeni (17 ha) and Xigalo (30 ha). The second was that during revitalisation, parts of the command area were excluded, as in the case of Tshiombo Block 1A (8 ha) and Makuleke (204 ha).

At Tshiombo Block 1A (Fig.3), which was converted from canal to floppy irrigation, various small parts of the command area were not used because they did not fit the layout of the new irrigation system. At Makuleke, centre pivots limited use of the command area to selected parts of the scheme that were sufficiently large and homogeneous to accommodate a centre pivot. The food plot section of the scheme was never revitalised and remained non-operational at the time of the survey. Palmaryville lost $1.3 \mathrm{ha}$, when the demonstration plot was privatised.

\subsection{Irrigation scheme development in Vhembe}

The post-WWII period up to 1969 was very important for smallholder irrigation scheme development in Vhembe. Seven schemes with a total command area of 659.6 ha were 


\begin{tabular}{|c|c|c|c|c|c|c|c|}
\hline Scheme name & Operational & $\begin{array}{c}\text { Number of } \\
\text { years } \\
\text { operational }\end{array} \mid$ & $\begin{array}{l}\text { Command } \\
\text { area (ha) }\end{array}$ & $\begin{array}{c}\text { Number of } \\
\text { plot } \\
\text { holders }\end{array}$ & $\begin{array}{c}\text { Average } \\
\text { plot size } \\
\text { (ha) }\end{array}$ & $\begin{array}{c}\text { Hydraulic } \\
\text { head }\end{array}$ & $\begin{array}{c}\text { Irrigation } \\
\text { method }\end{array}$ \\
\hline Nesengani & Yes & 42 & 13.7 & 28 & 0.415 & Pumped & Surface \\
\hline Nesengani B1 & No & 17 & 20.6 & 116 & 0.178 & Pumped & Overhead \\
\hline Nesengani B2 & No & 17 & 40.9 & 116 & 0.352 & Pumped & Overhead \\
\hline Nesengani C & No & 17 & 31.2 & 131 & 0.238 & Pumped & Overhead \\
\hline Dzindi & Yes & 56 & 136.2 & 102 & 1.285 & Gravity & Surface \\
\hline Khumbe & Yes & 56 & 145.0 & 138 & 0.623 & Gravity & Surface \\
\hline Dzwerani & No & 20 & 124.0 & 248 & 0.500 & Pumped & Overhead \\
\hline Palmaryville & Yes & 59 & 92.0 & 70 & 1.296 & Gravity & Surface \\
\hline Lwamondo & No & 6 & 15.0 & 75 & 0.200 & Pumped & Micro \\
\hline Mauluma & Yes & 45 & 38.0 & 30 & 1.267 & Gravity & Surface \\
\hline Mavhunga & Yes & 45 & 47.5 & 32 & 1.532 & Gravity & Surface \\
\hline Raliphaswa & Yes & 46 & 15.0 & 13 & 1.154 & Gravity & Surface \\
\hline Mandiwana & Yes & 46 & 67.0 & 40 & 1.675 & Gravity & Surface \\
\hline Mamuhohi & Yes & 46 & 77.0 & 61 & 1.262 & Gravity & Surface \\
\hline Mphaila & Yes & 21 & 70.6 & 59 & 1.197 & Pumped & Overhead \\
\hline Luvhada & Yes & 58 & 28.8 & 79 & 0.365 & Gravity & Surface \\
\hline Rabali & Yes & 59 & 87.0 & 68 & 1.279 & Gravity & Surface \\
\hline Mphepu & Yes & 49 & 132.8 & 133 & 0.998 & Gravity & Surface \\
\hline Tshiombo 1 & Yes & 48 & 60.5 & 47 & 1.287 & Gravity & Surface \\
\hline Tshiombo 1a & Yes & 1 & 128.6 & 100 & 1.286 & Pumped & Overhead \\
\hline Tshiombo 1b & Yes & 45 & 122.0 & 115 & 1.061 & Gravity & Surface \\
\hline Tshiombo 2 & Yes & 46 & 126.0 & 98 & 1.286 & Gravity & Surface \\
\hline Tshiombo 2a & Yes & 48 & 173.5 & 114 & 1.522 & Gravity & Surface \\
\hline Tshiombo 3 & Yes & 45 & 128.4 & 100 & 1.286 & Gravity & Surface \\
\hline Tshiombo 4 & Yes & 46 & 56.0 & 112 & 0.500 & Gravity & Surface \\
\hline Lambani & No & 4 & 260.0 & 16 & 16.250 & Pumped & Surface \\
\hline Phaswana & No & 8 & 16.7 & 16 & 1.044 & Pumped & Surface \\
\hline Cordon A & Yes & 45 & 43.7 & 38 & 1.150 & Gravity & Surface \\
\hline Cordon B & Yes & 45 & 82.3 & 65 & 1.266 & Gravity & Surface \\
\hline Phadzima & Yes & 45 & 102.3 & 103 & 0.993 & Gravity & Surface \\
\hline Makuleke & Yes & 2 & 37.3 & 29 & 1.286 & Pumped & Overhead \\
\hline Rambuda & Yes & 58 & 170.0 & 132 & 1.288 & Gravity & Surface \\
\hline Murara & Yes & 42 & 70.0 & 7 & 10.000 & Gravity & Surface \\
\hline Dopeni & Yes & 46 & 30.0 & 6 & 5.000 & Gravity & Surface \\
\hline Makhonde & No & 10 & 83.0 & 58 & 1.431 & Pumped & Micro \\
\hline Sanari & No & 17 & 17.0 & 11 & 1.870 & Pumped & Micro \\
\hline Tshikonelo & No & 14 & 10.0 & 15 & 0.670 & Pumped & Overhead \\
\hline Chivirikani & Yes & 28 & 68.3 & 112 & 0.609 & Pumped & Overhead \\
\hline Gonani & Yes & 13 & 8.5 & 30 & 0.295 & Pumped & Overhead \\
\hline Folovhodwe & Yes & 54 & 70.0 & 24 & 2.197 & Gravity & Surface \\
\hline Klein Tshipise & Yes & 36 & 60.0 & 60 & 1.000 & Gravity & Surface \\
\hline Morgan & Yes & 40 & 56.7 & 35 & 1.620 & Gravity & Surface \\
\hline Makumeke & Yes & 5 & 17.0 & 63 & 0.269 & Pumped & Micro \\
\hline Dovheni & Yes & 11 & 60.0 & 14 & 2.143 & Pumped & Overhead \\
\hline Mangondi & No & 15 & 48.0 & 38 & 1.260 & Pumped & Micro \\
\hline Xigalo & Yes & 5 & 22.0 & 24 & 1.080 & Pumped & Micro \\
\hline Garside & Yes & 45 & 13.7 & 28 & 0.415 & Gravity & Surface \\
\hline Malavuwe & Yes & 19 & 20.6 & 116 & 0.178 & Pumped & Overhead \\
\hline
\end{tabular}

Table 2. Selected characteristics of the population of smallholder irrigation schemes in Vhembe District 


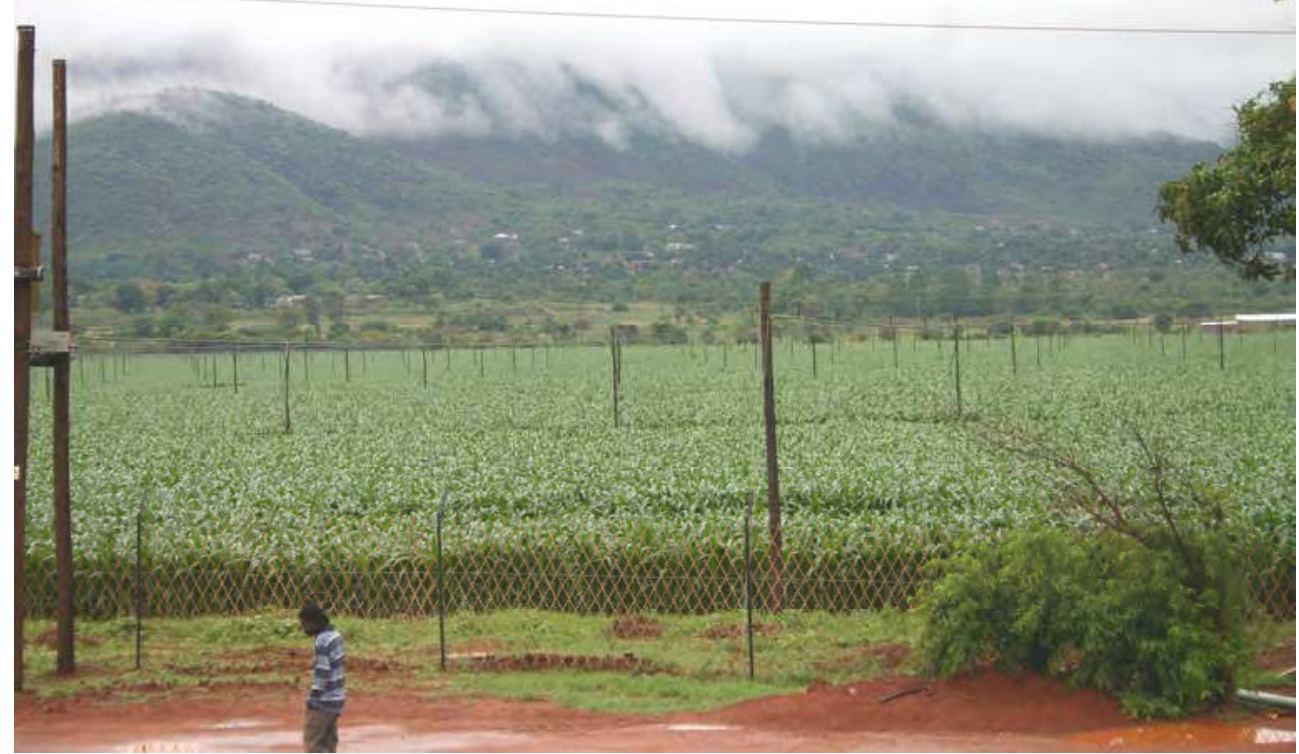

Fig. 3. Revitalisation of Tshiombo Block 1A replaced the secondary canals and concrete furrows that conveyed water to the edge of individual farmers' fields with a centrally operated floppy sprinkler system that covers the entire hydraulic unit

established between 1951 and 1959. An additional 21 schemes with a total command area of 1978 ha were constructed during the decade that followed. This means that 2637.6 ha $(70 \%$ of the existing smallholder irrigation scheme command area in Vhembe) were established between 1951 and 1969. All of the schemes that were constructed during this period were canal schemes. Nesengani, established in 1968, was the only canal scheme that made use of a pump to extract water to small concrete reservoirs from where it was gravitated to the plots. All other canal schemes extracted water by means of a weir or by means of spring diversion and relied entirely on gravity to convey water to the plots. All but one of the schemes that were constructed as canal schemes remained operational as canal scheme in 2009 but several had been fully or partially refurbished. The only exception was Block 1A of Tshiombo, which was recently (2008-09) transformed into a floppy irrigation scheme.

The period 1970 to 1979, which saw the construction of the last two canal schemes in Vhembe, namely Morgan and Klein Tshipise (Fig.4) in 1974, was a quiet period for smallholder irrigation development. Renewed activity occurred from 1980 onwards and was associated with the commencement of homeland self-government (Beinart 2001). All smallholder irrigation schemes that were established from 1980 onwards used pumps and pressurised irrigation systems. Dzwerani, established in 1980, was the first pressurised smallholder irrigation scheme in Vhembe. Non-operational at present, the 128 ha scheme at Dzwerani involved the pumping of water from the Dzondo River close to the confluence with the Dzindi River and the application of water by means of dragline sprinklers. Dzwerani was unique in 
that the 0.5 ha irrigation plots were also used for residential purposes. The idea for this development followed a visit by President Mphephu of the Venda homeland to Israel, where he observed similar arrangements. Dzwerani became a presidential pet project that received full financial support towards the cost of pumping and also towards other inputs, resulting in the development of a high degree of dependency on the state among the plot holder community. The project stopped operating when the pump was washed away during the 2000 flood. During the period 1980 to 1989, 10 of the existing schemes came into being with a combined command area of 495.8 ha. An additional 8 schemes were created between 1990 and 1999, with a combined command area of 506.7 ha. Most of these schemes were developed before 1998, when the homeland agricultural parastatals were still operational.

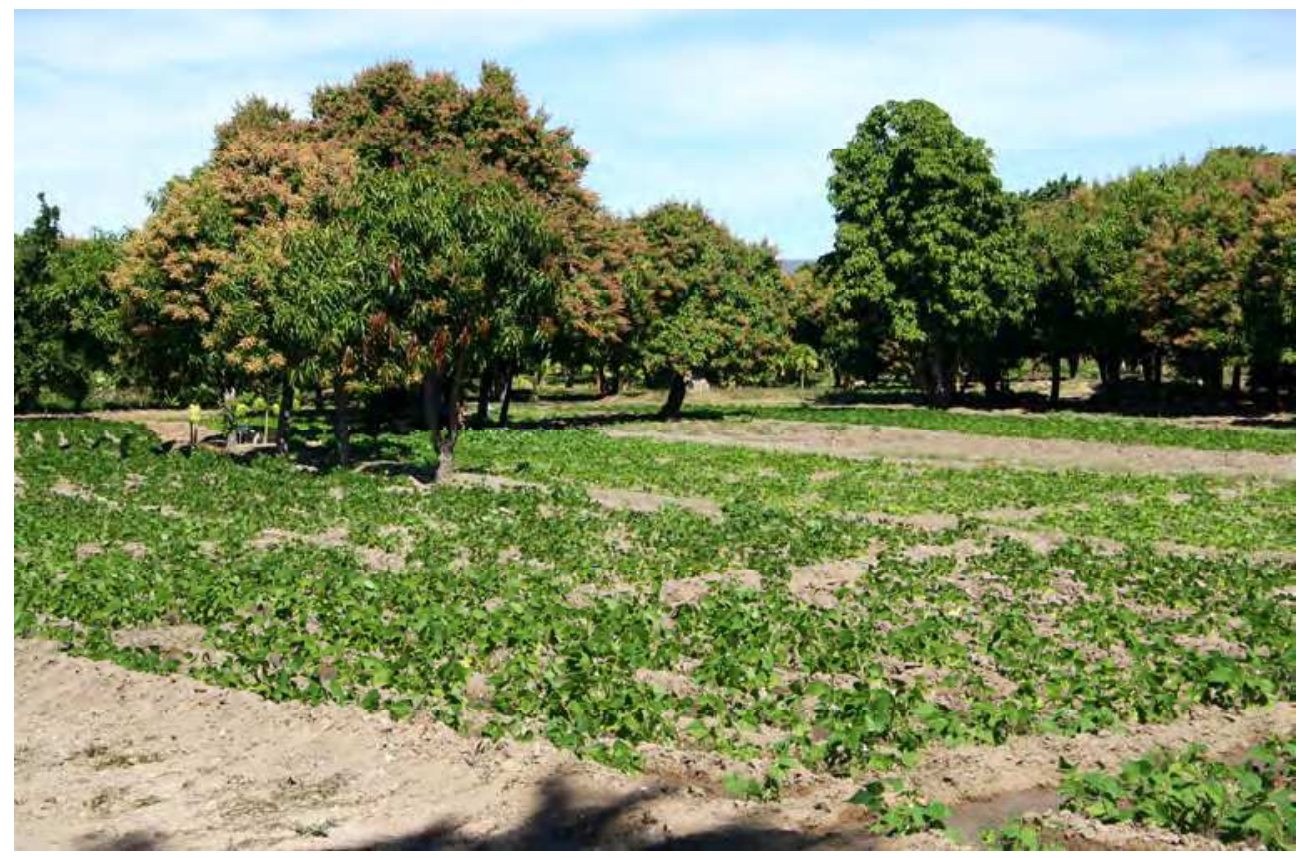

Fig. 4. The 8.5 ha Klein Tshipise scheme sourced its water from a spring and was the last canal scheme to be constructed in Vhembe, which occurred in 1974

During the first decade of the $21^{\text {st }}$ century, the emphasis of state intervention was on revitalisation of existing schemes rather than on the creation of new schemes. Only two new schemes were established during this period, covering a modest command area of 120 ha. By the end of 2009, 10 of the 48 schemes covering a command area of 902.3 ha $(24.0 \%)$ had been completely revitalised. Another 12 schemes covering a command area of 1083.3 ha (28.8\%) had been partly revitalised and an additional two schemes with a combined command area of 61.5 ha $(1.6 \%)$ were being revitalised. This brought the total number of schemes that had benefited from revitalisation, or would so soon, to 24 , which was exactly half of the total. Combined the schemes that benefitted from revitalisation support covered $54.4 \%$ of the total smallholder scheme command area of 3760.1 ha, which left 1713 ha (45.6\%) untouched. 


\subsection{Plot holder populations and plot sizes}

Smallholder scheme land in Vhembe was held by a total of 3250 plot holders. Makhonde, with 7 plot holders was the scheme with the smallest plot holder population, whilst Tshiombo, when its seven sub-units were combined, had the largest with 660 plot holders. Dividing the total command area of the smallholder schemes by the total number of plot holders showed that on average, a Vhembe plot holder held 1.1570 ha of land, of which 0.8286 was operational irrigation land. However, plot size varied among the schemes. The smallest average plot size (0.178 ha) was found at Nesengani B1. Phaswana had the largest average plot size. The most common average plot size ranged between 1.01 ha and 1.5 ha and was found on 22 schemes. Plots in this size range were also dominant among the population of plot holders. A total of 1431 plot holders (44\%) held plots that fitted in this size class.

\subsection{Water sources, extraction and adequacy}

Extraction of water directly from rivers using pumps or by means of weir diversion were the two most common ways in which smallholder schemes sourced their irrigation water. Spring water was used at two of the smaller schemes, namely Klein Tshipise ( 8.5 ha) and Luvhada (28.8 ha) and at Garside, spring water was used as a supplementary source. Makuleke was the only scheme that obtained its water from a dam. Surface irrigation, which invariably involved the use of short furrow irrigation (Fig.5), was dominant and occurred on 28 of the 48 schemes. All other methods of applying water were of secondary importance, perhaps with the exception of micro-irrigation (micro jet and drip), which was found on eight schemes but only two of these were operational in 2009.

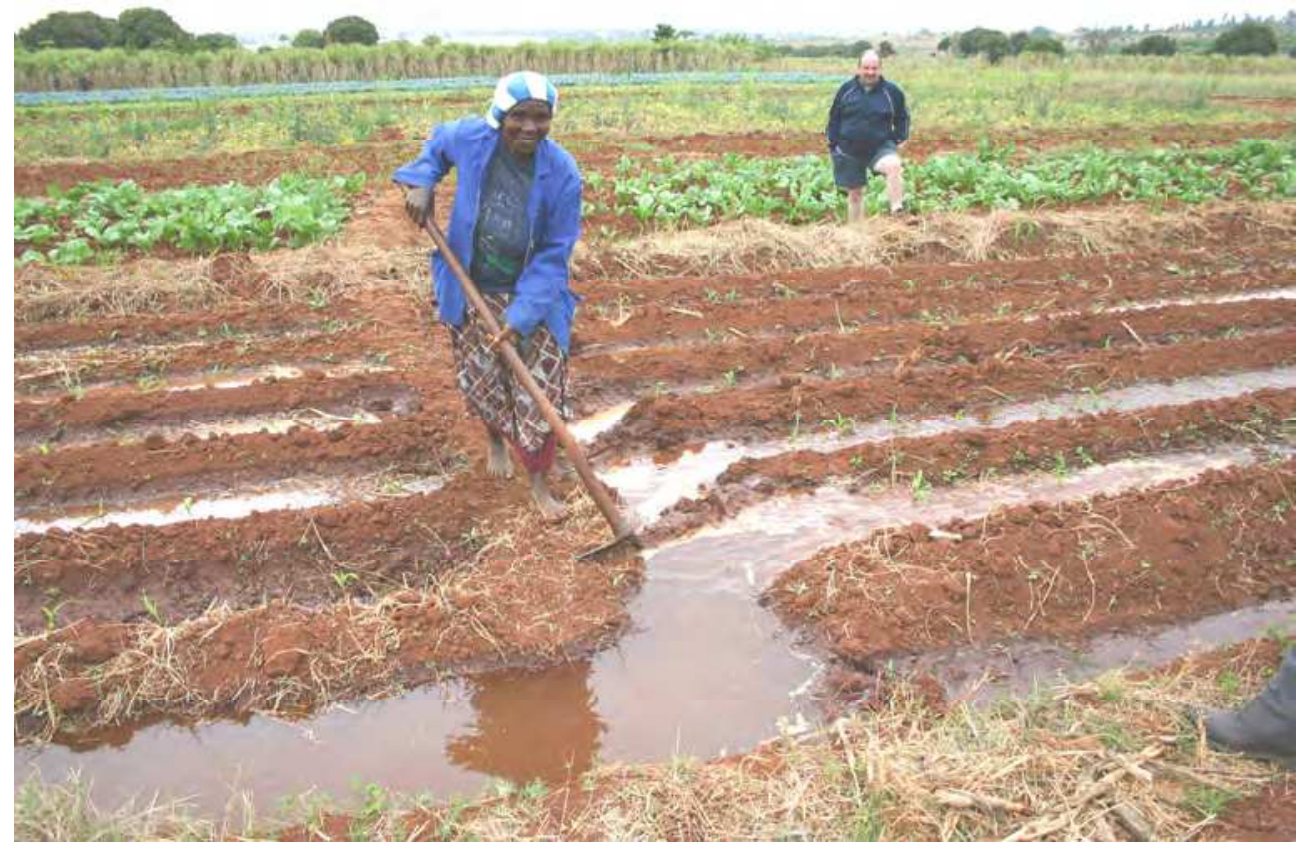

Fig. 5. Short furrow irrigation at the Dzindi canal scheme 
Generally, irrigation water availability was reasonably adequate, because only 5 of the 48 schemes reported year-round limitations, whilst on 21 schemes availability was said to be unlimited. Seasonal limitations in availability were mostly encountered on canal schemes. Four of the five schemes that reported availability to be always limited consisted of the last four irrigation blocks of Tshiombo, where lack of water was caused, at least in part, by the front-end blocks extracting more than their share, leaving too little for the tail-end blocks. Front-end tail-end differences in access to water among farmers were commonly reported on canal schemes. Mangondi, a drip irrigation scheme that was not operational in 2009, was the other scheme where water was always limited. Here the problem appeared not to be the source (Levhubu River) but rather the way the extraction system had been set up. Farmers used various ways of dealing with lack of irrigation water. In order of frequency of occurrence these included reducing the area planted to crops $(53 \%)$, exchanging water among themselves $(49 \%)$, stealing water from others $(44 \%)$, reducing the frequency of irrigation (42\%), irrigating at night (33\%), planting crops that required less water $(27 \%)$ and extracting water privately from the source using portable pumps $(7 \%)$.

Only 27 schemes had a water license issued by the Depart of Water Affairs. Payment for water occurred at 17 schemes but water was paid for by the Limpopo Department of Agriculture, not the farmers. Water user associations had been established on 28 schemes, but with few exceptions these were not functional. Participation of scheme communities in catchment management activities was limited to a single case. On all but five schemes, management of water extraction and distribution was in the hands of an elected plot holder committee. At Tshiombo Block 1A and Makuleke, the commercial partner was in control and at Sanari (micro irrigation) and Dovheni (designed as a sprinkler line scheme), there was no management organisation and farmers were allowed to draw water whenever they wanted. At Phaswana, water management was the responsibility of the farmer cooperative, but the scheme was no longer operational.

Formal water management rules (captured in writing) had been drawn up at 37 schemes. At one scheme rules existed but had not been written up. The remaining schemes had no rule system in place to manage water. These included Lwamondo (collapsed micro irrigation scheme), Phaswana (non-operational micro irrigation scheme), Tshiombo Block 1A and Makuleke (revitalised schemes that had a commercial partner, who operated the scheme) and the pressurised schemes of Gonani and Dovheni, where water availability was said not to be limiting.

\subsection{Land tenure and exchange}

The Trust tenure system was by far the most prevalent tenure system on smallholder irrigation schemes in Vhembe. The implication was that land identified for the development of irrigation schemes had been detribalised and transferred to the state before the scheme was constructed. Trust tenure is regarded as the least secure of all systems that applied to African land holding and has been identified as a possible reason for the lack of land exchanges on smallholder irrigation schemes (Van Averbeke, 2008). Schemes with traditional tenure were usually established quite recently but there was one exception. Luvhada, a project developed in 1952 by the community of Mphaila without state assistance also had traditional tenure. Despite the prevailing Trust system of tenure, land exchanges occurred on $72 \%$ of the schemes, which was more common than expected. On schemes 
where land exchanges occurred the basis for the exchange in order of importance was cash $(82 \%)$, free land preparation of own parcel $(52 \%)$, a share of the crop $(27 \%)$ and just as a favour $(9 \%)$. The maximum duration of land exchange arrangements on schemes where such arrangements occurred was more than two years in $67 \%$ of the cases, up to two years in $12 \%$ of the cases and limited to a single season in $21 \%$ of the cases.

\subsection{Farming systems, cropping intensity and degree of commercialisation}

The most common farming system involved the production of grain (mostly maize) and vegetables. This farming system was found on $73 \%$ of the schemes. The crops that were incorporated in this farming system served both as food crops for own consumption and as crops than could be sold locally (Fig.6).

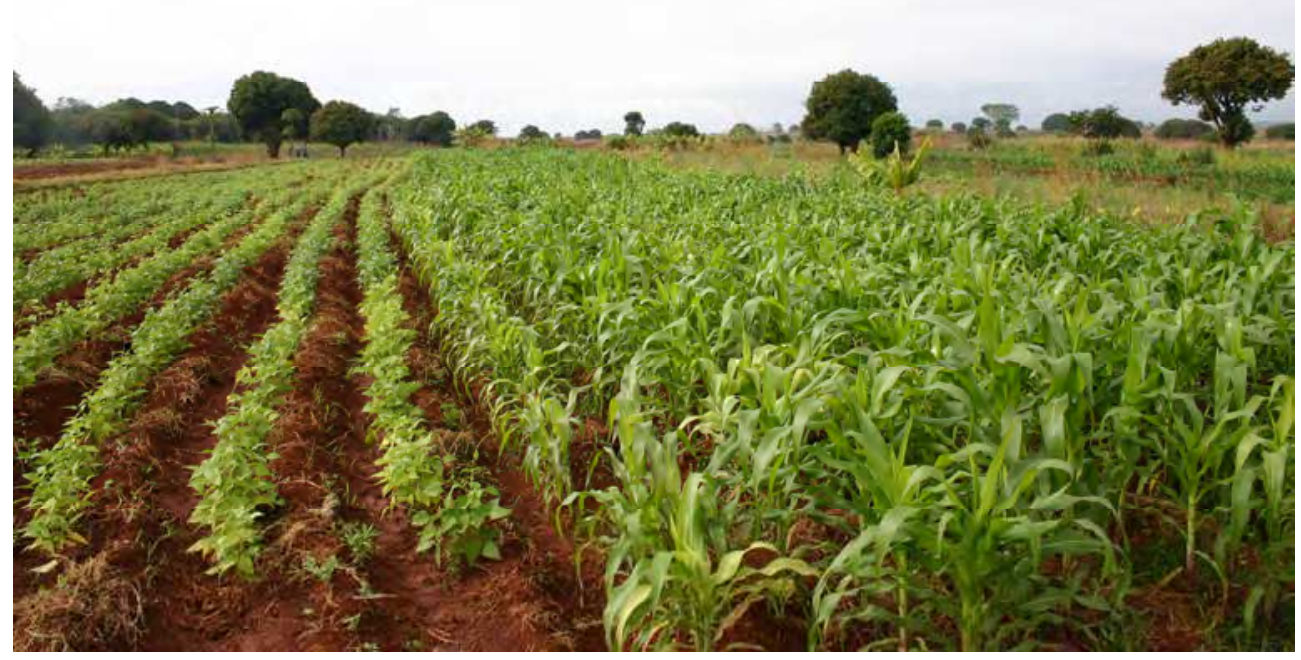

Fig. 6. The main farming system on smallholder irrigation schemes involved the production of maize and vegetables, both of which could be used for own consumption or sales

All other farming systems (primarily tropical fruit) were less important. In most cases they were established through the intervention of a homeland parastatal or through the implementation of the Joint Venture model. This model transferred control of the scheme to a commercial partner. In return for the release of their land for use by the Joint Venture, plot holders received dividends, which amounted to half of the net operating income. Cropping intensity varied considerably among the schemes. The majority of schemes had cropping intensities that ranged between 0.8 and 1.6. Schemes with cropping intensities higher than 1.2 were considered to be really active. The highest cropping intensity of 2.0 was found at Tshiombo Block 1A and Makuleke. Both were Joint Venture schemes where the commercial 
partner did all the farming. Across operational schemes, the proportion of produce that was sold was $50.6 \%$, which was about 5\% higher than the $45 \%$ recorded in the 1952 survey of smallholder irrigation schemes by the Tomlinson Commission (1955). The difference was partially due to the exceptionally high proportion of produce sold $(99 \%)$ at the Makuleke and Tshiombo Block 1A Joint Venture schemes.

\section{Performance assessment}

The results of the statistical analysis of the association of the four performance indicators and selected characteristics of smallholder irrigation schemes in Vhembe are summarised in Table 3. All 48 schemes were included in the analysis of operational status and durability (number of years in operation). For the analysis of cropping intensity and degree of commercialisation, all non-operating schemes and the two schemes where a strategic partner was doing all the farming were excluded from the analysis.

\begin{tabular}{|l|c|c|c|c|}
\hline \multirow{2}{*}{ Scheme characteristic } & \multicolumn{4}{|c|}{ Performance indicator } \\
\cline { 2 - 6 } & $\begin{array}{c}\text { Operational } \\
\text { status } \\
(\mathrm{n}=48)\end{array}$ & $\begin{array}{c}\text { No of years in } \\
\text { operation } \\
(\mathrm{n}=48)\end{array}$ & $\begin{array}{c}\text { Cropping } \\
\text { intensity } \\
(\mathrm{n}=35)\end{array}$ & $\begin{array}{c}\text { Degree of } \\
\text { commercialisation } \\
(\mathrm{n}=35)\end{array}$ \\
\hline Hydraulic head & $-0.618(0.000)$ & $-0.848(0.000)$ & $0.057(0.187)$ & $0.270(0.029)$ \\
\hline Irrigation method & $-0.707(0.000)$ & $-0.847(0.000)$ & $0.189(0.071)$ & $0.373(0.007)$ \\
\hline Scheme area & $0.154(0.074)$ & $0.394(0.002)$ & - & - \\
\hline No of plot holders & - & $0.348(0.004)$ & - & - \\
\hline Plot size & - & $0.019(0.225)$ & $0.104(0.104)$ & $0.212(0.055)$ \\
\hline $\begin{array}{l}\text { Organisation of } \\
\text { production }\end{array}$ & - & $-0.266(0.018)$ & - & - \\
\hline $\begin{array}{l}\text { Water restrictions at } \\
\text { scheme level }\end{array}$ & - & - & $-0.438(0.002)$ & $-0.031(0.215)$ \\
\hline $\begin{array}{l}\text { Cash based land } \\
\text { exchanges }\end{array}$ & - & - & $-0.014(0.235)$ & $-0.019(0.229)$ \\
\hline Water theft & - & - & $-0.244(0.041)$ & - \\
\hline $\begin{array}{l}\text { Effectiveness of scheme } \\
\text { fence }\end{array}$ & - & - & $-0.070(0.174)$ & - \\
\hline Distance to urban centre & - & - & $0.067(0.171)$ & $-0.436(0.002)$ \\
\hline
\end{tabular}

Table 3. Spearman's rank correlation coefficients and exact probabilities (bracketed) of the associations between four performance indicators and selected characteristics of smallholder irrigation schemes in Vhembe

\subsection{Operational status}

The correlation between the operational status of smallholder irrigation schemes in Vhembe and hydraulic head was fairly strong $(-0.618)$ and statistically highly significant. The negative correlation coefficient indicated that gravity-fed schemes were more likely to be (and remain) operational than pumped schemes. The correlation between operational status and irrigation method was even stronger $(-0.707)$. This suggested that schemes employing micro irrigation were less likely to be operational than schemes using overhead irrigation. Schemes using surface irrigation were most likely to be operational but this was to be expected because on all gravity-fed schemes plot holders made use of the short furrow method to apply irrigation water. 


\subsection{Durability}

The number of years schemes had operated, or had been in operation, before they collapsed, was very strongly correlated with hydraulic head (-0.848) and irrigation method (0.847). The negative sign of both correlations indicated that canal schemes were considerably more durable than pumped schemes. The positive, statistically significant $(\mathrm{p}<0.01)$ correlation between scheme area and number of years in operation and between number of plot holders and number of years in operation were probably the result of the co-variation of these two factors with hydraulic head. On average, the plot holder population on gravity-fed schemes (71) was slightly larger than on pumped schemes (63) and the average scheme area of gravity-fed schemes ( $83.4 \mathrm{ha}$ ) was also larger than that of pumped schemes (55.7 ha). The statistically significant $(\mathrm{p}<0.05)$ negative correlation between organisation of production and number of years in operation indicated that group projects were less likely to last than projects where plot holders farmed individually. Plot size did not appear to affect durability of irrigation schemes.

\subsection{Cropping intensity}

Associations between cropping intensity and scheme characteristics were not very strong. Of all the scheme characteristics that were tested, cropping intensity was most strongly correlated with water restrictions at scheme level $(\mathrm{r}=-0.438)$. This negative correlation, which was statistically highly significant $(p<0.01)$, indicated that water restrictions, mostly due to seasonal differences in the supply of the source, inhibited farmers from using their plots as intensively as possible. The weak but statistically significant $(p<0.05)$ negative correlation between the occurrence of water theft and cropping intensity was probably the result of water restrictions causing water theft and not due to differences in the degree of social order at the schemes. Hydraulic head, effectiveness of the scheme fence and distance to the nearest urban centre appeared not to affect cropping intensity. Cropping intensity tended to be positively correlated with irrigation method (micro irrigation $>$ overhead irrigation $>$ surface irrigation) but the correlation was not statistically significant ( $p>0.05)$. Surprisingly, cropping intensity was not associated with the presence or absence of cash based land exchanges among plot holders.

\subsection{Degree of commercialisation}

Associations between degree of commercialisation and scheme characteristics were also not strong. Of all the scheme characteristics that were tested, degree of commercialisation was most strongly correlated with distance to the nearest urban centre $(r=-0.436)$. The relative strength of this correlation indicated that access to local urban markets was a significant factor in determining the orientation of production of plot holders on smallholder irrigation schemes. Remoteness, which reduced access to markets, resulted in farmers focussing more on producing for own consumption. Hydraulic head $(\mathrm{r}=0.270)$ and method of irrigation (0.373) were positively correlated with degree of commercialisation. This indicated that plot holders on pumped schemes tended to orient their farming more towards markets than those on gravity-fed schemes and that commercialisation was stimulated by the use of overhead and micro irrigation. Degree of commercialisation tended to be correlated positively with plot size, but this correlation was not statistically significant $(p>0.05)$. It needs pointing out that among the schemes that featured in the analysis of degree of 
commercialisation, the range in average plot size among schemes was limited, with the smallest plots being 0.295 ha and the largest 2.197 ha. Water restrictions and the prevalence of cash-based land exchanges did not appear to affect degree of commercialisation.

\section{Discussion}

In this study it was demonstrated that gravity-fed canal schemes, on which farmers practised short furrow irrigation, were more likely to be operational and to last longer than pumped schemes. This was in line with the observations of Crosby et al. (2000) and Shah et al. (2002) for South Africa at large. They pointed out that pumped schemes tended to offer better quality irrigation than gravity-fed schemes and that pumping costs helped to impose financial discipline. However, they also stated that pumped schemes were more vulnerable to breakdown and that the cost of pumping tended to squeeze the net operating income of farm enterprises. An analysis of smallholder irrigation projects in Kenya concluded that pumped schemes operated and maintained by groups of smallholders were not sustainable (Scheltema, 2002). All of these projects had collapsed even before it was time to replace the pump, because of their higher financial and organisation requirement relative to gravity-fed schemes. The current study also indicated that pumped schemes were more vulnerable to flood damage than gravity schemes, mainly because during heavy flooding, pumps were washed away.

Generally, the cropping intensity on the smallholder schemes in the study area was well below the optimum values of 1.5 to 2.5 suggested by Faurès et al. (2007) but higher than the cropping intensity of 0.45 recorded by Mnkeni et al. (2010) at the Zanyokwe smallholder irrigation scheme in the Eastern Cape. Under conditions of adequate water supply, the subtropical climate of Vhembe puts the achievement of cropping intensities of 2 and more within reach. The study showed that water restrictions were a significant factor in determining cropping intensity. The water restrictions encountered on schemes in Vhembe were mostly seasonal and were caused by fluctuations in supply at source, in line with the prevailing summer rainfall pattern. Reductions in cropping intensity in response to water restrictions were also observed by Perry \& Narayanamurthy (1998) in Asia. The absence of any evidence of an association between cropping intensity and cash-based land exchanges (rentals) among plot holders contradicted the assertion of Tlou et al. (2006) that land tenure was the most important system on system factor in irrigated agriculture. Other researchers have also suggested that the development of land rentals would increase cropping intensity on smallholder irrigation schemes in South Africa (Shah et al., 2002; Van Averbeke, 2008) but the results obtained in this study did not support this anticipated effect.

Degree of commercialisation on smallholder irrigation schemes in Vhembe was found to be associated with the location of schemes in relation to local urban centres. As distance between scheme and urban centre increased, farmers were less likely to produce for marketing purposes. Van Averbeke (2008) reported that marketing of farmer's produce at the Dzindi Canal Scheme, which also formed part of the current study, was mainly in the hands of street traders. Street traders purchased fresh produce from farmers in small quantities on a daily basis and most of them (66 of 84) were sedentary traders, who retailed this produce to the public in areas characterised by heavy pedestrian flows, such as the main streets in towns and townships and at the entrance of hospitals. The other 18 street traders were mobile. They retailed produce in villages and townships that 
surrounded Dzindi, carrying a bag of produce on their heads as they moved from door to door. Bakkie traders, who purchased produce in larger quantities and transported this produce in their vans to the same type of trading places as those of street traders, also purchased produce at Dzindi, but relative to street traders, they were less important. Nearly all 66 sedentary traders who purchased fresh produce at Dzindi used combi-taxis to transport their produce to their retail places and 54 of the 66 used taxis to get to the urban centre of Thohoyandou where they sold the produce. Taxi fares between Dzindi and Thohoyandou were relatively cheap, because of the short distance. Therefore, the negative correlation between degree of commercialisation and distance between scheme and nearest urban centre suggests that the cost of taxi fares could well be the factor that determines whether or not it is financially viable for sedentary street traders to purchase from scheme farmers and travel to urban centres to sell. During the field work it was noted that when schemes were located far away from an urban centre, farmers mainly sold produce to residents around the scheme, to mobile street traders, who retailed door to door and to bakkie traders. The absence of sedentary street traders purchasing fresh produce in these remote schemes, contrary to Dzindi, is a plausible explanation for the negative correlation between degree of commercialisation and distance to urban centres, which was also reported by Magingxa et al. (2009) for a sample of smallholder schemes in various other parts of South Africa.

\section{Conclusion}

The study of factors affecting the performance of smallholder irrigation schemes in Vhembe District yielded several interesting results, which have implications for smallholder irrigation scheme policy. Smallholder canal schemes were more likely to be operational and to last longer than pumped schemes. This finding questions the desirability of converting canal schemes into pumped schemes, which has been the practice of the RESIS Recharge Programme of the Limpopo Department of Agriculture. The study results suggest that rehabilitating existing canal systems would most probably be more sustainable. The study also indicated that in the absence of external interventions, commercialisation among farmers on smallholder schemes was more likely to occur when schemes were located close to urban centres, because proximity made it financially viable for street traders to travel between scheme, as the place of purchase, and town, as the place of retail, using public transport. This is important when the development of new schemes is being considered. For remote schemes, external intervention aimed at supporting market access appeared to be necessary to enhance commercialisation. At this stage, few of the farmer-managed schemes received marketing support from external agencies. Efforts to that effect are recommended and should be facilitated by public extension services in collaboration with the private sector. Finally, the study results indicated that the two smallholder irrigation schemes that were consolidated and farmed as single entities by a strategic partner (commercial farmer) were characterised by high cropping intensities and high degrees of commercialisation. However, the sustainability of this revitalisation trajectory is highly questionable. The introduction of centre pivot or floppy systems largely prevent plot holders from repossessing their schemes and farms as individuals once the joint venture arrangement comes to an end. As was already pointed out by Crosby et al. (2000), 'the worst scenario (for smallholder irrigation scheme development) is where central management not only takes all decisions unilaterally on a top-down basis but also conducts all on-farm operations'. 


\section{Acknowledgement}

Research towards this chapter was conducted as part of the solicited WRC Project K5/1464/4, entitled, "Best Management Practices for Small-Scale Subsistence Farming on Selected Schemes and Surrounding Areas through Participatory Adaptive Research", which was initiated, managed and funded by the Water Research Commission (WRC) and the nonsolicited WRC Project K5/1804/4, entitled, "Improving Plot Holder Livelihood and Productivity on Smallholder Canal Irrigation Schemes in Limpopo Province", that was managed and funded by the WRC. The author wishes to thank Mr J Denison for his valuable contribution to the design of the survey instrument, Mr K Ralivhesa for his assistance during the fieldwork, Mrs L Morey of the Biometry Division of the Agricultural Research Council for statistical analysis of the data and my daughter Lerato Van Averbeke for useful suggestions on how to improve the readability of the text. The contributions to the study made by smallholders on irrigation schemes in Vhembe and by staff of the Department of Agriculture in the Vhembe District and the Thulamela, Makhado, Musina and Mutale Municipalities are also gratefully acknowledged.

\section{References}

Aliber, M., \& Hart, T. (2009). Should Subsistence Agriculture Be Supported as a Strategy to Support Rural Food Insecurity? Agrekon, Vol.48, No.4, (December 2009), pp. 434458, ISSN 0303-1853

Backeberg, G.R. (2006). Reform of User Charges, Market Pricing and Management of Water: Problem or Opportunity for Irrigated Agriculture. Irrigation and Drainage, Vol.55, pp.1-12, ISSN 1531-0361

Backeberg, G.R., \& Groenewald, J.A. (1995). Lessons from the Economic History of Irrigation Development for Smallholder Settlement in South Africa. Agrekon, Vol.34, No.3, pp. 167-171, ISSN 0303-1853

Beinart, W. (2001). Twentieth Century South Africa. Oxford University Press, ISBN 0-19289318-1, Oxford, UK

Beinart, W. (2003). The Rise of Conservation in South Africa: Settlers, Livestock and the Environments 1770-1950. Oxford University Press, ISBN 978-0-19-926151-2, Oxford, UK

Bembridge, T.J. (1997). Small-Scale Farmer Irrigation in South Africa: Implications for Extension. South African Journal of Agricultural Extension, Vol.26, pp. 71-81, ISSN 0301-603X

Bembridge, T.J. (2000). Guidelines for Rehabilitation of Small-Scale Farmer Irrigation Schemes in South Africa, WRC Report No 891/1/00, Water Research Commission, ISBN 186845-683-8, Gezina, South Africa

Bembridge, T.J., \& Sebotja, I. (1992). A Comparative Evaluation of Aspects of the Human Impact of Three Irrigation Schemes in Lebowa. South African Journal of Agricultural Extension, Vol.21, pp.30-41, ISSN 0301-603X

Bundy, C. (1988). The Rise and Fall of the South African Peasantry, Second Edition, David Philip, Cape Town, South Africa

Christie, F., \& Hanlon, J. (2001). Mozambique \& The Great Flood of 2000, James Currey, ISBN 085255-857-0, Oxford, UK 
Commission for the Socio-Economic Development of the Bantu Areas within the Union of South Africa (1955). Summary of the Report, The Government Printer, Pretoria, South Africa

Crosby, C.T., De Lange, M., Stimie, C.M., \& Van der Stoep, I. (2000). A Review of Planning and Design Procedures Applicable to Small-Scale Farmer Irrigation Projects, WRC Report No 578/2/00, Water Research Commission, ISBN 1-86845-688-9, Gezina, South Africa

De Lange, M., Adendorff, J., \& Crosby, C.T. (2000). Developing Sustainable Small-Scale Farmer Irrigation in Poor Rural Communities: Guidelines and Check Lists for Trainers and Development Facilitators, WRC Report No. 774/1/00. Water Research Commission, ISBN 1-86845-692-7, Gezina, South Africa

Denison, J., \& Manona, S. (2007). Principles, Approaches and Guidelines for the Participatory Revitalisation of Smallholder Irrigation Schemes: Volume 2 - Concepts and Cases, WRC Report No TT 309/07, Water Research Commission, ISBN 978-1-77005-569-8, Gezina, South Africa

De Wet, C. (2011). Where Are They Now? Welfare, Development and Marginalization in a former Bantustan Settlement in the Eastern Cape, In: Reforming Land and Resource Use in South Africa: Impact on Livelihoods, P. Hebinck \& C Shacleton, (Ed.), 294-314, Routledge, ISBN 978-0-415-58855-3, Milton Park, Abingdon, UK

Economic Development Department (23 November 2010). The New Growth Path: The Framework. Available from

http:/ / www.info.gov.za/view/DownloadFileAction?id=135748

Fanadzo, M., Chiduza, C., Mnkeni, P.N.S., Van der Stoep, I., \& Stevens, J. (2009). Crop Production Management Practices as a Cause for Low Water Productivity at Zanyokwe Irrigation Scheme. Water SA Vol.36, No.1, (January 2010), pp. 27-36, ISSN 1816-7950 (On-line)

Faurès, J-M., Svendsen, M., \& Turral, J. (2007). Reinventing irrigation, In: Water for Food Water for Life: A Comprehensive Assessment of Water Management in Agriculture, D. Molden (Ed.), 353-394, Earthscan, ISBN 978-1-84407-396-2, London, UK

Houghton, D.H. (1955). Life in the Ciskei: A Summary of the Findings of the Keiskammahoek Rural Survey 1947-51, SA Institute of Race Relations, Johannesburg, South Africa

Inocencio,A., Kikuchi, M., Tonosaki, M., Maruyama, A., Merrey, D., Sally, H., \& De Jong, I. (2007). Cost and Performance of Irrigation Projects: A Comparison of Sub-Sharan Africa and Other Developing Regions. IWMI Research Report 109, International Water Management Institute, ISBN 978-92-9090-658-2, Colombo, Sri Lanka

Kamara, A., Van Koppen, B., \& Magingxa, L. (2001). Economic Viability of Small-Scale Irrigation Systems in the Context of State Withdrawal: The Arabie Scheme in the Northern Province of South Africa, Proceedings of the Second WARSFA/Waternet Symposium: Integrated Water Resource Management: Theory, Practice, Cases, pp. 116128, Cape Town, South Africa, October 30-31, 2001

Khandlhela, M., \& May, J. (2006). Poverty, vulnerability and the impact of flooding in the Limpopo Province of South Africa. Natural Hazards Vol. 39, pp. 275-287, ISSN 1573-0840 (electronic)

Lahiff, E. (2000). An Apartheid Oasis? Agriculture and Rural Livelihoods in Venda, Frank Cass, ISBN 0-7146-5137-0, London, UK 
Laker, M.C. (2004). Development of a General Strategy for Optimizing the Efficient Use of Primary Water Resources for Effective Alleviation of Rural Poverty, WRC Report No KV 149/04, Water Research Commission, ISBN 1-77005-208-9, Gezina, South Africa

Leibbrandt, M., \& Sperber, F. (1997). Income and Economic Welfare, In: From Reserve to Region - Apartheid and Social Change in the Keiskammahoek District of (former) Ciskei: 1950-1990, C. De Wet \& M. Whisson (Ed.), 111-152, Institute for Social and Economic Research, Rhodes University, ISBN 0-86810-331-4, Grahamstown, South Africa

Letsoalo, S.S., \& Van Averbeke, W. (2006). Water Management on a Smallholder Canal Irrigation Scheme in South Africa. In: Water governance for Sustainable Development: Approaches and Lessons from Developing and Transitional Countries, S. Perret, S Farolfi, \& R. Hassan (Ed.), 93-109, Earthscan, ISBN-13 978-1-84407-319-1, London, UK

Lewis, J. (1984) The Rise and Fall of the South African Peasantry: A Critique and Reassessment, Journal of Southern African Studies, Vol. 11, No. 1, (October 1984), pp. 1-24, ISSN 0305-7070

Lipton, M. (1996). Rural Reforms and Rural Livelihoods: The Context of International Experience, In: Land, Labour and Livelihoods in Rural South Africa, Volume One: Western Cape, M. Lipton, M. De Klerk \& M. Lipton, (Ed.), 1-48, Indicator Press, ISBN 1-86840-234-7, Dalbridge, Durban, South Africa

Makhura, M.T., Goode, F.M., \& Coetzee, G.K. (1998). A Cluster Analysis of Commercialisation of Farmers in Developing Rural Areas of South Africa. Development Southern Africa, Vol. 15, No. 3 (Spring 1998), pp. 429-445, ISSN 0376$835 \mathrm{X}$

Machethe, C.L., Mollel, N.M., Ayisi, K., Mashatola, M.B., Anim, F.D.K., \& Vanasche, F. 2004. Smallholder Irrigation and Agricultural Development in the Olifants River Basin of Limpopo Province: Management Transfer, Productivity, Profitability and Food Security Issues, WRC Report No: 1050/1/04, Water Research Commission, ISBN 1-77005242-9, Gezina, South Africa

Magingxa, L.L., Alemu, Z.G., \& Van Schalkwyk, H.D. (2009) Factors Influencing Access to Produce Markets for Smallholder Irrigators in South Africa. Development Southern Africa, Vol. 26, No.1 (March 2009), pp 47-58, ISSN 0376-835X

Mills, M.E.E., \& Wilson, M. (1952). Land Tenure, Shuter and Shooter, Pietermaritzburg, South Africa

Mnkeni, P.N.S., Chiduza, C., Modi, A.T., Stevens, J.B., De Lange, M., Adendorff, J., \& Dladla, R. (2010). Best management Practices for Smallholder Farming on Two Irrigation Schemes in the Eastern Cape and KwaZulu-Natal Through Participatory Adaptive Research. WRC Report No TT 478/10, Water Research Commission, ISBN 978-1-4312-0059-7, Gezina, South Africa

Molden, D., Sakthivadivel, R., Perry, C.J., De Fraiture, C., \& Kloezen, W.H. (1998). Indicators for Comparing Performance of Irrigated Agricultural Systems, IWMI Research Report 20, International Water Management Institute, ISBN 92-9090356-2, Colombo, Sri Lanka

Scheltema, W. (2002). Smallholder Management of Irrigation in Kenya, In. The Changing Face of Irrigation in Kenya: Opportunities for Anticipating Change in Eastern and Southern Africa, H.G. Blank, C.M. Mutero \& H. Murray-Rust, (Ed.), 171-189, International Water Management Institute, ISBN 92-9090-475-5, Colombo, Sri Lanka 
Shah, T., Van Koppen, B., Merrey, D., De Lange, M., \& Samad, M. (2002). Institutional Alternatives in African Smallholder Irrigation: Lessons from International Experience with Irrigation Management Transfer Management Transfer, IWMI Research Report 60, International Water Management Institute, ISBN 92-9090-481-X, Colombo, Sri Lanka

Stayt, H.A. (1968). The BaVenda, Second Impression, Frank Cass, London, UK

Tlou, T., Mosaka, D., Perret, S., Mullins, D., \& Williams, C.J. (2006). Investigation of Different Farm Tenure Systems and Support Structure for Establishing Small-Scale Irrigation Farmers in Long Term Viable Conditions, WRC Report No 1353/1/06, Water Research Commission, ISBN 1-77005-475-8, Gezina, South Africa

Tomlison Commision (1955) see Commission for the Socio-Economic Development of the Bantu Areas within the Union of South Africa

Turral, H., Svendsen, M., \& Faurès, J.M. (2010). Investing in Irrigation: Reviewing the Past and Looking to the Future. Agricultural Water Management, Vol. 97, pp. 551-560, ISSN 0378-3774

Umhlaba (2010). A Review of Experiences of Establishing Emerging Farmers in South Africa: Case Lessons and Implications for Farmer Support within Land Reform Programmes, Food and Agricultural Organization of the United Nations, ISBN 978-92-5- 106490-5, Rome, Italy

Van Averbeke, W. (2008). Best Management Practices for Small-Scale Subsistence Farming on Selected Irrigation Schemes and Surrounding Areas through Participatory Adaptive Research in Limpopo Province, WRC Report No TT 344/08, Water Research Commission, ISBN 978-1-77005-689-3, Gezina, South Africa

Van Averbeke, W., \& Hebinck, P. (2007). Contemporary Livelihoods, In: Livelihoods and Landscapes: The People of Guquka and Koloni and their Resources, P. Hebinck \& P.C. Lent, (Ed.), 285-306, Brill, ISBN 978-90-04-16169-6, Leiden, The Netherlands

Van Averbeke, W., M'Marete, C.K., Igodan, C.O., \& Belete, A. (1998). An Investigation into Food Plot Production at Irrigation Schemes in Central Eastern Cape, WRC Report No 719/1/98, Water Research Commission, ISBN 1-86845-334-0, Gezina, South Africa

Van Rooyen, C.J., \& Nene, S. (1996). What can we learn from Previous Small Farmer Development Strategies in South Africa? Agrekon, Vol. 35, No. 4 (December 1996), pp. 325-331, ISSN 0303-1853

Vermillion, D.L. (1997). Impacts of Irrigation Management Transfer: A Review of the Evidence, Research Report 11, International Irrigation Management Institute, ISBN 92-9090340-5, Colombo, Sri Lanka

Vink, N., \& Kirsten, J. 2003. Agriculture in the National Economy, In: The Challenge of Change: Agriculture, Land and the South African Economy, L. Nieuwoudt \& J Groenewald (Ed.), 3-19, University of Natal Press, ISBN 1-86914-032-X, Pietermaritzburg, South Africa

Vink, N., \& Van Rooyen, J. (2009). The Economic Performance of Agriculture in South Africa since 1994: Implications for Food Security. Development Planning Division Working Paper No 17, Development Bank of Southern Africa, Halfway House, South Africa 


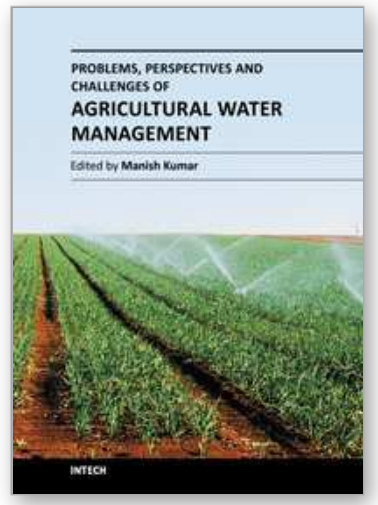

\section{Problems, Perspectives and Challenges of Agricultural Water Management \\ Edited by Dr. Manish Kumar}

ISBN 978-953-51-0117-8

Hard cover, 456 pages

Publisher InTech

Published online 09, March, 2012

Published in print edition March, 2012

Food security emerged as an issue in the first decade of the 21 st Century, questioning the sustainability of the human race, which is inevitably related directly to the agricultural water management that has multifaceted dimensions and requires interdisciplinary expertise in order to be dealt with. The purpose of this book is to bring together and integrate the subject matter that deals with the equity, profitability and irrigation water pricing; modelling, monitoring and assessment techniques; sustainable irrigation development and management, and strategies for irrigation water supply and conservation in a single text. The book is divided into four sections and is intended to be a comprehensive reference for students, professionals and researchers working on various aspects of agricultural water management. The book seeks its impact from the diverse nature of content revealing situations from different continents (Australia, USA, Asia, Europe and Africa). Various case studies have been discussed in the chapters to present a general scenario of the problem, perspective and challenges of irrigation water use.

\section{How to reference}

In order to correctly reference this scholarly work, feel free to copy and paste the following:

Wim Van Averbeke (2012). Performance of Smallholder Irrigation Schemes in the Vhembe District of South Africa, Problems, Perspectives and Challenges of Agricultural Water Management, Dr. Manish Kumar (Ed.), ISBN: 978-953-51-0117-8, InTech, Available from: http://www.intechopen.com/books/problems-perspectivesand-challenges-of-agricultural-water-management/performance-of-smallholder-irrigation-schemes-in-thevhembe-district-of-south-africa

\section{INTECH}

open science | open minds

\section{InTech Europe}

University Campus STeP Ri

Slavka Krautzeka 83/A

51000 Rijeka, Croatia

Phone: +385 (51) 770447

Fax: +385 (51) 686166

www.intechopen.com

\section{InTech China}

Unit 405, Office Block, Hotel Equatorial Shanghai

No.65, Yan An Road (West), Shanghai, 200040, China 中国上海市延安西路65号上海国际贵都大饭店办公楼405单元

Phone: +86-21-62489820

Fax: +86-21-62489821 
(C) 2012 The Author(s). Licensee IntechOpen. This is an open access article distributed under the terms of the Creative Commons Attribution 3.0 License, which permits unrestricted use, distribution, and reproduction in any medium, provided the original work is properly cited. 